\title{
(息)
}

Citation:

Nunn, A and Price, S (2005) Managing Development: EU and African Relations through the evolution of the Lomé and Cotonou Agreements. Historical Materialism, 12 (5). ISSN 1465-4466 DOI: https://doi.org/10.1163/1569206043505220

Link to Leeds Beckett Repository record:

https://eprints.leedsbeckett.ac.uk/id/eprint/1004/

Document Version:

Article (Published Version)

The aim of the Leeds Beckett Repository is to provide open access to our research, as required by funder policies and permitted by publishers and copyright law.

The Leeds Beckett repository holds a wide range of publications, each of which has been checked for copyright and the relevant embargo period has been applied by the Research Services team.

We operate on a standard take-down policy. If you are the author or publisher of an output and you would like it removed from the repository, please contact us and we will investigate on a case-by-case basis.

Each thesis in the repository has been cleared where necessary by the author for third party copyright. If you would like a thesis to be removed from the repository or believe there is an issue with copyright, please contact us on openaccess@leedsbeckett.ac.uk and we will investigate on a case-by-case basis. 
Alex Nunn and Sophia Price

\section{Managing Development: EU and African Relations through the Evolution of the Lomé and Cotonou Agreements}

\section{Introduction}

The relationship between the European Union ${ }^{1}$ and Africa has been formalised since the beginning of the European integration project in the evolving Yaoundé, Lomé and now Cotonou Agreements. The relationship has shifted in line with the emerging global framework for neoliberal accumulation. This shift has involved the 're-designing' of developmental strategies and their 'locking-in' in the long term. Theoretically, this global shift in the organisation of both production and social relations (including popular understandings) has been well documented and the changing dominant patterns of production in advanced industrial economies has been highlighted at length. However, this article aims to develop further the idea of 'locking-in', outlined in the work of Stephen Gill, and to place an increased emphasis on the phenomena of both re-designing and locking-in as they apply to the alteration of developmental strategies in Less Developed Countries

1 The European Community (EC) is used when referring exclusively to the period before the creation of the European Union (EU) in November 1993. 
(LDCs), among which those in Africa have suffered from extreme marginalisation and exploitation. This article reveals the often ignored role of the EU in this process. It argues that the EU, through its institutionalised link with Africa, has played a key role in re-designing developmental strategies to complement the global shift to neoliberal accumulation which, in its latest phase, is aimed particularly at the complex, multifaceted and increasingly integrated project to 'lock-in' the gains of capital over labour on a global scale. The article begins with a brief introduction to the complementary projects of 're-designing' and 'locking-in' before considering these against the historical evolution of the Lomé and Cotonou relationship.

\section{Re-designing and locking in}

This article uses an analytical model of locking-in developed from the work of Stephen Gill to understand the evolution of the Lomé, then Cotonou trade and aid relationship between the EU and the African, Caribbean and Pacific (ACP) group of developing states. As applied here, this model is developed to be explicitly multi-dimensional, reflecting the pursuit of this project across the different aspects (or pillars) of capitalist hegemony, different spatial levels and the differences between elements which are related to the dominance of capital over labour per se and those that seek to manage that relationship at any point in time and in the context of the balance of class power. Before elaborating this analytical model, it is necessary to briefly introduce some of the key concepts that underpin it.

Gill's use of 'locking-in' is heavily influenced by the analysis of the structural power of capital over the institutional framework of the state developed in Charles Lindblom's seminal 1977 work Politics and Markets. ${ }^{2}$ This concept explains how the needs of capital are prioritised in public policy and the management of the economy, especially over the long term, even in states with all the formal trappings of democracy and the separation of powers. Concrete examples of this structural power lie in the ability of capital to withhold investment, either in the economy as a whole, thereby inducing slower growth or recession, or from a specific government by withdrawing support through government bonds and other short- and long-term government financing mechanisms. ${ }^{3}$ The result, argues Gill, is that governments increasingly

3 Gill and Law 1993, p. 100. 
have to prove the credibility and consistency of their policies to secure the confidence of capital markets. ${ }^{4}$

Gill takes this analysis further, abstracting it to the global level and arguing that, in an era of disciplinary neoliberalism, this structural power is increasingly being written into legal and quasi-constitutional arrangements that extend between states and multilateral institutions and more nebulous rules-based frameworks, creating what he refers to as a 'new constitutionalism'. For Gill, the new constitutionalism is not only reflective of the hegemony of capital over labour, but of a specific form of hegemony, influenced by the policy dictates of neoliberalism and crucially offering a privileged position to specific classes and class factions:

... new constitutionalism operates in practice to confer privileged rights of citizenship and representation to corporate capital and large investors. What is being attempted is the creation of a political economy and social order where public policy is premised upon the dominance of the investor, and reinforcing the protection of his/her property rights. The mobile investor becomes the sovereign political subject. ${ }^{5}$

Gill draws heavily on Gramsci's notion of hegemony, as being self-reflexive, actively constructed and incorporating both consensual and coercive features. Neoliberal hegemony, Gill argues, is characterised by the pursuit of measures to 'reconfigure' state apparatuses, and construct markets and measures to deal with the dislocations created by the circulation of fictitious commodities. This last category of characteristics of neoliberal hegemony draws significantly upon Polyani's idea of the 'double movement' to both extend commodification and socialise the core elements of capitalist production, and can be broken down into three sub-categories. These are: measures to protect against the contradictions generated by the commodification of capital, to contain the contradictions created by the commodification of land (that is, sustainable development and other aspects of environmental protection), and measures to contain the effects of the commodification of labour. ${ }^{6}$

Clearly, however, if the 'locking-in' of the policy prescriptions of neoliberal hegemony is to take this form, then the structural power of capital over the state must be significantly modified to allow the state to secure the necessary

$\begin{array}{ll}{ }^{4} & \text { Gill } 1998 . \\ { }^{5} \text { Gill 1998, p. } 1 . \\ { }^{6} \text { Gill 1998, p. } 4 .\end{array}$ 
conditions for the reproduction of accumulation. Conceptually, this can be accounted for via an understanding of the concept of the relative autonomy of the state. This autonomy is possible, first, because various factions of capital themselves do not share a singular and unified set of interests beyond the structural dominance of capital over labour, and, second, by the reality of class struggle in which the state becomes a mediating institution between capital and labour:7

This organisation of the proletarians into a class, and consequently into a political party, is continually being upset again by the competition between workers themselves. But it ever rises up again, stronger, firmer, mightier. It compels legislative recognition of particular interests of the workers, by taking advantage of the divisions among the bourgeoisie itself. Thus the ten hours bill in England was carried. ${ }^{8}$

At any one time, then, the state has varying degrees of freedom from individual fractions of capital and can broker alliances to intervene in the structural base of the economy.

The state is able to play this role in organising and unifying the bourgeoisie and the power of the bloc in so far as it enjoys relative autonomy of given fractions and components, and of various political interests. Such autonomy is indeed constitutive of the capitalist state: it refers to the state's materiality as an apparatus relatively separated from the relations of production, and to the specificity of classes and class struggle under capitalism that is implicit in that separation. ${ }^{9}$

Paul Cammack ${ }^{10}$ has recently applied this concept to the governance of global capitalism, in which organisations and networks of organisations embody the political autonomy conferred upon the state at the domestic level and explains the conceptual underpinnings of the new constitutionalism. At this level, relatively autonomous political authority takes shape in organisations and institutions, more nebulous régimes of rules, dominant ideas and in the form of multilateral treaties and agreements. Each of these operates at a variety of spatial levels. This is the first dimension of locking-in and focuses

\footnotetext{
Cammack 2003, pp. 41-2.

8 Marx and Engels 1985, p. 90.

9 Poulantzas 2000, p. 127.

10 Cammack 2003.
} 
analytical attention on the role of the management of global capitalism at various spatial abstractions such as the global, macro-regional (that is, Europe, East Asia, and so forth), national and sub-national levels, down to communities, families and individuals.

The second dimension of 'locking-in' is demonstrated by giving more explicit recognition to what is often implicit in Gill's work: that locking-in extends beyond the process of the formal constitutionalism that he identifies, encompassing the requirements of neoliberal accumulation across a range of 'pillars' of hegemony. These include a technical/legal pillar, a social/sociopsychological pillar and a political/institutional pillar.

In a technical-legal sense, locking-in involves the reconstruction of legal frameworks which protect the rights of capital over a long and often defined period. This is manifest for instance, in contract and property law (including intellectual property) designed to guard against the expropriations that had marked dependency and Keynesian-inspired development policies. This technical-legal aspect is explicitly linked to change in the political and institutional pillar. The result is to promote and build the interests of investors into the rules of the system itself and therefore remove them from the everyday political agenda. Crucially, such political change is intended to prevent an easy (re)turn to alternatives to neoliberalism. This pillar is also the site of reform of welfare systems and other institutions designed to mediate the negative effects of accumulation and contain elements of the class compromise that might otherwise drop out of the formal capitalist economy. The reform of social systems in this way has been critical in the transition between the early phase of neoliberal reform, focusing on austerity-based deconstruction of prior structures of more developmental and Keynesian political economy, and more recent reforms designed to expand the available pool of labour and, more crucially, shift the focus of intervention to relative surplus-value generation.

Social/socio-psychological locking-in refers to the management of social practices, norms and expectations. For instance, throughout the 1970s and early 1980s, the International Monetary Fund (IMF) and World Bank often remarked on the importance of downgrading the expectations of subordinate social groups and classes for redistribution of the social surplus of production. Again, this example demonstrates how locking-in within each of the pillars of hegemony combines and relate to one another. Socio/psychological lockingin clearly relates to measures to undermine redistribution, either privately 
through measures to lower wages relative to surpluses, or publicly through measures to cut taxation and public spending. Both in the core and periphery, this initially involved 'austerity' measures, including 'cold bath' reductions in employment and public spending. As the World Bank and European Commission have remarked illustratively of the transition economies of Eastern Europe, the socio-psychological 'shock' of crisis is an important part of this process:

Rapid action can improve the political sustainability of reform if it prevents a joint assault by special interest groups.... Bold changes are especially necessary if a government lacks credibility. ... A conclusive reform can help to reshape expectations about the government's commitment and so contribute to its success. Governments do well to capitalize on the broad, potentially short lived mandate for reform that crisis confers by front loading the reform program. ${ }^{11}$

Protracted and endemic shortages, inflation and hyperinflation are a great problem but also mollify the population and reduce popular resistance to shock therapy ... unpopular measures should not be spread over time but taken as quickly as possible. ${ }^{12}$

Again, austerity-based adjustments to social expectations form part of the early phase of constructing neoliberal hegemony, with the major part of the focus on deconstruction of earlier manifestations of an alternative developmental hegemony. More recently, locking-in has developed a more sophisticated approach, mediated through the ideology of the Third Way, promoted by strategically important politicians and states. In terms of social practices and expectations, this phase has not merely focused on coercive aspects of locking-in but has sought also to mobilise consensual strategies. Shaped against the backdrop of fear of resistance to structural adjustment and the rise of 'dropping out' of the formal economy, ${ }^{13}$ these strategies have become a major element in the drive to expand and lock-in commodification, particularly with regard to expanding the pool of available,

11 World Bank 1991, p. 117.

12 European Commission 1992, pp. 8-11. Emphasis ours.

13 While the informal economy may be capitalist too, it is difficult for political authority to manage and regulate and as such exists on the margins of hegemony outside of the direct scope of measures to increase commodification and to contain its contradictions. 
flexible and competitive labour - Marx's reserve army of labour - in strategies designed to increase the rate of absolute surplus-value. These have been combined with measures to raise expectations in relation to education and health care - so called pro-poor policies - to boost the quality of labour inputs (and potential inputs) in measures designed to raise the rate of relative surplus-value. ${ }^{14}$

As a result, development policies in the 1990s have increasingly been presented as participatory, with a social dimension and owned by the domestic population, and this has been reflected in the evolution of the Lomé and Cotonou relationship. This has involved various strategies including involving NGO partners in designing and implementing development programmes, engendering entrepreneurship at an ever more grassroots level and manipulating ideologies such as postmodernism and feminism to present neoliberal re-designing and locking-in programmes as individually empowering, in a process which is captured by Gramsci's concept of trasformismo. ${ }^{15}$

This leads to a consideration of the third dimension of locking-in. This is that hegemony consists of 'layers', in which the most foundational and deeply entrenched layer incorporates key elements of capitalist hegemony over labour, such as individual property rights, practices of wage-labour and the acceptance of contract law. Overlaid on this layer are more superficial elements of policy design which capture the active strategies to support, extend and defend accumulation in the particular context of the balance of class power. This understanding helps to illuminate how it is that capitalist hegemony is reconstructed in different formats but the central elements of exploitation and unequal power remain.

This article argues that the Lomé/Cotonou relationship has embodied just such a shift in hegemony, which has taken the form of a transition away from the social-democratic compromise of the welfare and developmental state. It is argued here that the active deconstruction of this compromise has been characteristic of the evolution of the Lomé/Cotonou relationship as it has

${ }^{14}$ Critical to these measures are understandings developed in bourgeois scholarship around the interaction of labour with capital and the ability to generalise and take up new production techniques and technologies. For more work on 'endogenous growth theory', particularly on innovation and learning by doing, see Kaldor and Mirlees 1962, Arrow 1962.

15 Gill 1999. 
been shifted away from preferential trade and aid cooperation with a heavy focus on developmentalism. This destructive element has taken the form of structural adjustment and 're-designing' of the state-society relationship in the ACP. In its place, an alternative form of hegemony has been increasingly reflected in the focus of the treaty, including measures to embed neoliberal flexible accumulation and to offset its contradictions largely through the adoption of the policy mantra of 'poverty reduction'. The success of this strategy has been determined by the ability of the EU and ACP to construct supportive class alliances. Thus, the Lomé/Cotonou relationship has increasingly incorporated measures designed to co-opt managerial and bureaucratic élites in the ACP through formal training programmes and institution building to facilitate 'partnership'.

A further important element in the shift in hegemony more broadly, and specifically in the Lomé/Cotonou agreements themselves, has been how the interests of blocs of capital have been mediated by those of relatively autonomous political authority at the level of the state, macro-region and globally. A key feature of the early Lomé framework was the inclusion of policies and measures which were clearly the product of demands from individual EU states to protect the interests of nationally embedded blocs of capital. It was this that led the agreements to be characterised in this early period as neocolonial, reflecting the continuation of dependence and uneven development without the formal trappings of imperialism. However, reflecting Gill's argument regarding the specific composition of neoliberal hegemony as being increasingly dominated by the interests of finance capital, the Lomé/Cotonou framework has taken a more generalised perspective of capitalist interests.

In advancing re-designing of the ACP state-society relationship and lockingin the policy prescriptions of neoliberalism, the EU-ACP relationship has taken its place within the broader institutional project that Gill describes and includes other important 'partners' such as the World Bank and IMF. Indeed, careful examination of the provisions of evolving Lomé and Cotonou agreements reveals that this relationship has often led the efforts of these institutions, incorporating important policy innovations prior to their appearance in the broader global development framework. 


\section{EU-African relations}

The relationship between the EU and Africa dates back to the creation of the EC, with Part IV of the 1957 Treaty of Rome outlining the framework for 'association' between the two regions, based on reciprocal preferential trade and aid provisions. ${ }^{16}$ This framework was modified by the two successive Yaoundé Conventions (1963-9 and 1969-74) ${ }^{17}$ in light of the move to independence by many of the associated states. The relationship provided the EC with a framework for the protection of economic and geopolitical interests. This was particularly true for France, as the Association and Yaoundé agreements represented devices to off-load French colonial mercantilism on to the Community as a whole in return for receiving access to markets and sources of supply. The relationship between the EC and this selective group of Southern states was tainted by the criticism of neocolonialism, as decisionmaking was unequal, colonial patterns of trade were little altered, per capita incomes were not significantly raised, and the newly independent states were kept in a position of economic and political dependence. ${ }^{18}$ Despite such critiques, the relationship endured, as the newly independent states and their ruling élites remained largely orientated to accepting neocolonial dependent development. ${ }^{19}$

The framework of relations between the EC and Africa was expanded and modified with the replacement of Yaoundé by the first Lomé Convention in 1975. UK accession to the EC necessitated the accommodation of links with a wider group of ACP states and this phase of the institutionalisation of the EU-ACP relationship was contextualised by the dominant conditions in the global political economy at a time of commodity price booms, oil price hikes and growing political instability in the core, as the postwar accumulation régime faltered. Combined with rising Third-World militancy, this context

16 Association applied to French West Africa (Dahomey, Guinea, Côte d'Ivoire, Mauritania, Niger, Senegal, Sudan and Upper Volta), French Equatorial Africa (Cameroon, Chad, Middle Congo, Gabon and Ubangi-Chari), other French territories of the Autonomous Republic of Togo, Madagascar, Comoros, French Polynesia, French Southern and Antarctic Territories, Algeria, Réunion, Guyanne, Martinique, Guadeloupe, St. Pierre and Miquelon, French Somaliland, New Caledonia and Dependencies, Belgian Congo and Ruanda-Urundi, Italian Somaliland and New Guinea.

17 These linked the EC to eighteen Associated African States and Madagascar (AAMS) (Burundi, Cameroon, Central African Republic, Chad, People's Republic of Congo (formerly Brazzaville), Dahomey, Gabon, Côte d'Ivoire, Madagascar, Mali, Mauritania, Niger, Rwanda, Senegal, Somalia, Togo, Upper Volta and Zaïre (formerly CongoKinshasa, Congo Leopoldville).

18 Curzon and Curzon 1971, p. 125; Gruhn 1976, p. 244; Ravenhill 1985, p. 33.

19 Green 1976, p. 5. 
motivated the EC to pursue a strategy to secure relations with valued overseas markets, exporters of raw materials (especially oil-producing states), and investment sites. ${ }^{20}$ As such, the new convention aimed to manage trade and investment environments and to provide a response to the dependency debate and calls for collective self-reliance and delinking. Hailed as an example of the New International Economic Order (NIEO), ${ }^{21}$ it focused on the practical issues surrounding North-South co-operation such as market access, compensatory finance and the disbursement of aid. However, the EC refused ACP demands for the inclusion of the specific elements of the NIEO agenda such as ACP national sovereignty over natural resources, adjustment of EU economies and a code of conduct for transnational enterprises. ${ }^{22}$

The first Lomé Convention reflected the dominance of dependency and Keynesian-inspired demands for national developmental autonomy through attempting to decommodify certain aspects of North-South relations. Price stabilisation, grant aid, technology transfer and preferential market access were all hailed as promoting Third-World interests and tessellated with nationalised industrialisation. Aid was predominantly in grant form, without the usual 'strings attached', while the trade régime provided preferential, non-reciprocal access for certain ACP exports to the European market. This interventionist approach to trade was supplemented by a system for the stabilisation of exports (STABEX) and separate protocols guaranteeing prices and quotas for certain commodities. While recognising the dependency of

${ }^{20}$ African states controlled significant energy resources. Nigeria was the world's eighth largest oil producer, whilst the Congo, Gabon, Zaire, and Trinidad controlled 1,300 million tons of proven oil resources. Oil companies were exploring the Cameroon, Dahomey, Ghana, Senegal and Ethiopia. In light of increased European reliance on nuclear energy, uranium supplies were of growing importance and were present throughout Central Africa, with Gabon, Niger, the Central African Republic and Zaïre all actually producing uranium. Gruhn 1976, p. 259. Furthermore ACP states were important hosts for European investment, particularly from the former metropoles whose corporations often enjoyed monopolies in the exploitation of mineral wealth. For example, the French government owned seventy per cent of the capital of the Equatorial Africa Oil Company (SPAFE) which exploited deposits in the Congo and Gabon, and the French Atomic Energy Commission had a one-third interest in the Air Mines Company (SOMAIR) created in 1967 to exploit Niger's uranium deposits. The French government was also involved in mining bauxite in the Cameroon, manganese in Gabon and potash in the Congo. Ravenhill 1985, p. 37.

${ }^{21}$ In reflection of the UN General Assembly's 1974 Programme of Action for a New International Economic Order.

${ }^{22}$ Ravenhill 1985, p. 338. 
many ACP states on a few primary commodities, these régimes supported European MNCs heavily involved in the production of ACP exports. ${ }^{23}$

\section{Re-designing and locking-in in the evolution of Lomé}

Over the lifespan of the Convention, the EU-ACP partnership has grown to include twenty-five European member states and seventy nine ACP states. ${ }^{24}$ It has been renegotiated every five years, with the latest negotiation in 2000, seeing the relationship renamed the Cotonou Agreement. Within its evolution there has been an emphasis, first, on re-designing the state-society relationship and, later, locking-in development strategies in accordance with the policy prescriptions of neoliberalism. The overarching framework for the EU-ACP relationship has gradually been redefined, moving the agreement from a redistributive, interventionist approach to one founded on the principles of free trade and neoliberal orthodoxy. In large part, this has been due to the dominance of the EU in the relationship and the embracing of the logic of 're-designing' within both groups. This redefinition is evident in a number of areas. The development discourse contained within the Convention changed rapidly from one of interdependence, equality and redistribution to that of participation in the global economy. By Lomé III (1983), the focus was explicitly shifted from state, to private-sector-led development, with a central role attributed to the individual, and was described as a 'minimally interventionist, catalytic form of assistance'. ${ }^{25}$ This approach was augmented under Lomé IV (1989), which further embraced re-designing, decentralised co-operation based

${ }^{23}$ These included German MNCs such as Saarbergwerkt, Belgian Petrofina and Royal Dutch Shell in the ACP mineral sector; Tate and Lyle, Booker McConnell and Unilever in the agricultural sector, particularly the Caribbean and African plantations, and many conglomerates operating across sectors like Brook Leibig's involvement in tea, coffee and cattle rearing in Africa. Long 1980.

${ }^{24}$ This includes forty-eight African states (Angola, Benin, Botswana, Burkina Faso, Burundi, Cameroon, Cape Verde, Central African Republic, Chad, Comoros, Congo, Côte d'Ivoire, Djibouti, DRC, Equatorial Guinea, Eritrea, Ethiopia, Gabon, The Gambia, Ghana, Guinea, Guinea Bissau, Kenya, Lesotho, Liberia, Madagascar, Malawi, Mali, Mauritania, Mauritius, Mozambique, Namibia, Niger, Nigeria, Rwanda, Sao Tomé and Principe, Senegal, Seychelles, Sierra Leone, Somalia, South Africa, Sudan, Swaziland, Tanzania, Togo, Uganda, Zambia and Zimbabwe), sixteen Caribbean states (Antigua and Barbuda, Bahamas, Barbados, Belize, Dominica, Dominican Republic, Grenada, Guyana, Haiti, Jamaica, St. Kitts and Nevis, St. Lucia, St. Vincent and the Grenadines, Suriname and Trinidad and Tobago), and fifteen Pacific States (Cook Islands, East Timor, Federated State of Micronesia Fiji, Kiribati, Marshall Islands, Nauru, Niue, Palau, Papua New Guinea, Samoa, Solomon Islands, Tonga, Tuvalu and Vanuatu).

25 European Commission 1995, p. 23. 
on civil-society participation, and individualised human rights. New provisions sought to redefine the role of the state as 'enabling' private-sector development in a number of ways. These included guaranteeing an open, transparent and stable regulatory and political environment and the provision of appropriate infrastructure, low labour and energy costs and supportive technical industries. ${ }^{26}$ Crucial to this was the demonstration of a 'locked-in' commitment to marketbased development.

Most recently, through the Cotonou Agreement, the EU-ACP relationship has formally become part of a Third-Way-inspired global poverty reduction strategy, embracing social and economic reform in partnership with the institutions of global economic governance. The EU and its member states are major creditors and donors to the IMF and World Bank-led Highly Indebted Poor Countries (HIPC) initiative, and the accompanying poverty reduction strategies. ${ }^{27}$ The inclusion within Cotonou of an EU-ACP agreement to cooperate on debt relief issues follows Council guidelines in 1996 which outlined dominant themes in European development policy:

The policy in this area is a decisive factor in ensuring, in the context of tight and efficient public finance management, a fair distribution of the fruits of growth and access to basic social services such as education and health, and in encouraging the emergence of an investment-friendly environment. Macroeconomic reforms can have sustainable effects only if they fully embrace the objectives of social, human development. ${ }^{28}$

Furthermore, the Cotonou Agreement embodies perhaps the most radical element of reform in the re-designing of the Lomé development framework, namely WTO compliance through the liberalisation of the non-reciprocal preferential trade régime. This marks the latest stage in the ongoing reconfiguration of the EU-ACP relationship and its coherence with the wider global development framework, enshrining the principles of rules-based multilateral liberalisation. Over time, the value of ACP preferential access has been downgraded as the number of states covered by the agreement has increased, while the EU has also extended its range of development cooperation agreements outside the Lomé/Cotonou framework and has been at the forefront of multilateral trade liberalisation. Furthermore, the Lomé

\footnotetext{
${ }^{26}$ European Commission 1997, p. 4.

27 European Council 2000.

28 European Council 2000.
} 
trade régime has done little but reinforce $\mathrm{ACP}$ dependence on the EU. Combined with pressure for WTO compliance, as witnessed by the 'banana wars', these factors provided the rationale for the replacement of the Lomé régime by Cotonou's Economic Partnership Agreements (EPAs) between the EU and sub-regional groupings within the ACP. The basis of the new régime is the subdivision of the ACP geographically and developmentally, through the categorisation of a group of 'least developed countries' (LDCs) and a group of richer middle-income countries (non-LDCs). EPAs based on freetrade agreements are being established between the EU and the groups of ACP non-LDCs considered in a position to do so. ${ }^{29}$ The EU 'Everything But Arms' (EBA) initiative formally provides LDCs non-reciprocal duty-free access to the EU market. However, in practice, the existence of regional groupings within the ACP containing both LDCs and non-LDCs makes this differentiation of treatment difficult.

Increased access to the EU market has been a principle that the ACP have continually demanded since the original Lomé Convention, when it became clear that the EC would protect its most sensitive sectors, such as agriculture and textiles. However, in pursuing increased access to the EU market, the ACP were unwilling to undergo reciprocal liberalisation. This proved irreconcilable with the EU's vision of trade reform, based on full GATT/WTO compliance. Gradually, the Lomé relationship has become fully integrated into a global development framework based on a neoliberal accumulation model.

\section{Locking-in}

Central to the neoliberal re-designing project have been locking-in strategies, which are essential to secure such policy orientations over the long term. The most obvious evidence of locking-in has been the creation and maintenance of the Lomé/Cotonou relationship itself, by which ACP states have committed themselves to a particular development framework under the management of the EU. Locking-in has also been pursued through the increasing conditionality attached to the provisions of the Conventions. This is an effective

${ }^{29}$ The creation of EPAs is to follow an eight year (from the signing of the agreement) preparatory period. The all EU-ACP negotiations began in 2000 with the second phase of EPA negotiations beginning in 2003. It is expected that the new arrangements will enter into force by 1 January 2008, with a 12-15 year transition period before becoming fully operational. 
strategy, given the level of reliance of ACP states on the Lomé relationship. The conditional nature of the Convention built on the ongoing reforms of Lomé's financial protocol. The EC initiated such reforms when it engineered the adaptation of the financial protocol's dispersal mechanisms, particularly with the introduction of sectoral programming under Lomé III (1983), institutionalising a larger, more orthodox donor role for the EC, congruent with the IMF and World Bank's collective management of the debt crisis. ${ }^{30}$ Veiled in terms of increased efficiency, flexibility and co-ordination, the Commission's remit was extended to the allocation of funds to individual states, the identification of sectors and programmes and policy implementation. ${ }^{31}$ The shift from the project-oriented approach to support for priority sectors or development 'themes' allowed the EC to expand its decisionmaking role and re-design those parts of the ACP economies it wished to promote. Historically, the EC had been extremely selective in terms of recipient sectors and states. Little aid was given to support the production of goods that might compete with European products, consequently, industrial funding focused on energy supplies. Under Lomé I, over forty per cent of rural funds were allocated to large agro-industrial projects, concentrating heavily on primary export crops, with only a tiny sum allocated to value-added agricultural and food processing. ${ }^{32}$ However, as the Convention matured, increasing focus was given to facilitating local processing, enabling the management of integrated production chains and the development of supportive class alliances.

Building on the sectoral approach, a specific structural adjustment support facility was included in Lomé IV (1989) which was described as the first 'North-South Agreement on the philosophy underlying structural adjustment'. ${ }^{33}$ This facility, prompted by the EC's participation in the 1987 World Bank-led Special Programme for Assistance to Africa, introduced an element of conditionality to the financial protocol. This was a marked change but did not undermine the attraction of EC grants, even with strings attached, in

30 See IMF 1983.

31 In contrast to the previous system, whereby the ACP state exchanged views with the EC on development objectives and priorities, under Lomé III the European Commission became involved in the preparatory stage. The Commission and main providers of aid assess the ACP states' economic and social situation, and identify focal sectors. The programming mission, led by the Commission and the European Investment Bank then creates an indicative programme with the national authorities, setting out the sectors chosen, aid guidelines and the means of implementation. European Commission 1986, p. 71.

32 Rubin 1978, p. 11.

${ }^{33}$ European Commission 1990, p. 8. 
comparison to the loans offered by other donors. In 1991, structural adjustment funds were withheld from fifteen states due to failure to adopt a satisfactory economic reform programme, demonstrating that conditionality was underpinned by effective disciplinary sanctions. ${ }^{34}$ Conditionality was formally extended in 1995 to the observance of human rights, the rule of law and democratic principles, using the twin tools of a suspension mechanism and special allocations to bring Lomé further in line with the wider global development framework and demonstrating both a consensual and coercive aspect to the process. ${ }^{35}$ The inclusion of 'political conditionality' into the Convention demonstrates mechanisms of technical/legal and political/ institutional locking-in. This was carried forward to the Cotonou Agreement along with a greater emphasis on efficiency and hence an enhanced role for the European Commission in project preparation and appraisal, particularly through the introduction of performance-related tranching of disbursements.

Various measures within the Lomé/Cotonou relationship demonstrate the technical/legal elements of locking-in, in order to protect the position of capital over the long term and ensure a secure investment environment. The Lomé Convention developed an investment framework which was hailed as 'unprecedented in similar multilateral agreements', ${ }^{36}$ and aimed to encourage fair and equitable treatment for investors, clear, stable and predictable investment conditions including insurance and guarantee systems. To complement the framework, the EC accorded itself a facilitating role in extending investment. In the late 1970s, such a role had been demanded by a consortium of mining companies in response to the rapid decline of European investment in Third-World mining, due in part to increased state control. ${ }^{37}$ The request to provide investment stabilisation and protection frameworks in turn prompted the Commission to urge other institutions, such as the

34 European Commission 1996, p. 3.

35 Suspension mechanisms related to violations of a 'democracy clause' were a standard part of European agreements with Latin-American and Central and EasternEuropean states. The EU had already resorted to the unilateral suspension of Lomé benefits because of alleged violations of human rights or democratic principles in ACP countries. In 1994 Community aid to eight ACP states was suspended or restricted because of the security situation, failure to move towards democracy or poor observance of human rights (European Commission 1996, p. 3).

36 European Commission 1985a, p. 22.

37 Between 1961 and 1973 the proportion spent on mining exploration by European companies fell from 57 per cent of their total expenditure to 13.5 per cent. This drop was particularly marked in Africa. European Commission 1979b, p. 31. 
World Bank and the International Finance Corporation, to widen their stabilisation efforts. ${ }^{38}$ The EC's investment facilitating role was explicitly outlined as helping ACP states to re-design their domestic economies to facilitate access to capital markets and encourage direct private European investment particularly through sub- and joint-contracting. ${ }^{39}$ With the promotion and facilitation of private foreign investment to the ACP, European development policy was explicitly presented as a vehicle for the extension of European capital in an increasingly competitive global economy while assuring secure and diverse supplies of raw materials, particularly energy. ${ }^{40}$ The desire to stimulate European economic growth converged with the needs of capital to secure the most profitable locations in terms of market access, production costs, raw materials and labour. Augmenting the contractual mechanisms that ensured the technical/legal elements of locking-in to secure favourable investment conditions was the inclusion of human rights as a fundamental principle explicitly linked to development, particularly the rights of the individual in comparison to notions of group and socio-economic rights.

The Lomé/Cotonou relationship has also featured socio-psychological elements of locking-in. Early neoliberal conditionalities attached to structural adjustment policies have not only ensured the political and institutional aspect of locking-in, but have also had a psychological effect on society. Austerity has shaped citizens' expectations of the state and is crucial to the project to dismantle prior forms of political economy. Under Lomé III, the move to a framework promoting re-designing, the privileging of private enterprise and the restoration of credit worthiness through export production included the imposition of such austerity measures. However, the locking-in of neoliberal hegemony has not merely been coercive. The realisation that the hard medicine of structural adjustment could engender social unrest, prompted the EU to develop a role under Lomé IV as supporter of Bretton-Woods-designed policies of reform. As such, it sought to mitigate the effects of enforced public spending cuts and liberalisation to ensure 'that the social repercussions are tolerable believing as it does that social development is an integral part of economic

38 Long 1980, p. 123.

39 European Commission 2000, part 1:4, article 23.

40 The Commission estimated that an energy gap would emerge in the 1980s due to scarcity of uranium and oil, threatening the survival of European industry. European Commission 1979a, p. xxv. A central concern was that mineral supply would shift from Africa to the USA, Canada and Australia, which were much stronger bargaining partners, or to third countries where other industrialised mineral users represented more powerful competition. 
progress and the promotion of civil society and democracy in Africa' ${ }^{41}$ This role, described as that of 'social fire-brigade' by Hewitt, ${ }^{42}$ included increased support for small and medium-sized enterprises (SMEs) and micro-projects, and directing adjustment funds to public services, especially health and education. Political and social sustainability was to be ensured through decentralised co-operation and participation reflecting the increasingly ThirdWay developmental approach. ${ }^{43}$

In sum, the reconfiguration of the EU-ACP relationship has fitted with the evolution of the global development framework which has, in turn, been shaped by the changing needs of capital accumulation. Enforcing and embedding the transition from nationalised production to providing conditions favourable to securing private investment has been a key element of the relationship, in compliance with the wider framework embodied in the structural adjustment policies of the World Bank. Favourable investment conditions were further promoted as the EU developed a partner role to encourage European capital to invest in the ACP. Conditionalities were added at the same time as entrenching the new orthodoxy for social and political stability by incorporating a requirement to promote human rights, democracy and the rule of law. However, despite EC attempts to lock-in political and economic re-designing and the promotion of foreign direct investment (FDI), there have been ongoing difficulties in attracting capital to the ACP, with only a handful of the more advanced and viable economies being successful in this regard. While internal and external European policies have worked to downgrade the value of ACP preferential access to the European market, the pursuit of trade liberalisation embodied by the replacement of the Lomé Convention by the Cotonou Agreement ensures WTO compliance. This has significance beyond the agreement itself, as the Cotonou framework is, in turn, important in ensuring the wider compliance of the developing world with multilateral liberalisation.

\section{Locking-in as a multi-levelled project}

Locking-in is a complex and multi-levelled project that encompasses a host of co-ordinated institutions and agreements at and between the global, macro-

\footnotetext{
41 European Commission 1996, p. 3.

42 Hewitt 1989, p. 308.

43 European Commission 1990, p. 8.
} 
regional, national and sub-state levels. ${ }^{44}$ The latest phase of the EU-ACP relationship has demonstrated coherence with the global development framework by becoming an explicit facet of that strategy. This reflects the ongoing expansion of the partnership, not only through the accession of member states to each group, but also through the inclusion of other institutions. Since the late 1970s, the EU has sought to include private investors and financial institutions in the Lomé relationship in order to fund joint projects, supplement stabilisation efforts and help spread risk. Contributors to these 'triangular financing' schemes were individual member states and the World Bank, as well as OPEC investors in the late 1970s who were eager to recycle petro-dollars. Despite ACP rejection of closer co-operation with the Bretton Woods institutions, European policy has increasingly been made in coordination with them 'in the interests of policy effectiveness and of Western co-ordination and solidarity'. ${ }^{45}$ This was particularly evident in the 1989 and 1995 Lomé Conventions, which clearly reflected World Bank structural adjustment programmes, a set of policies that have long been a tool to enforce re-designing, and institutionalised the inclusion of a social dimension to reforms. Through this process, the EU, in conjunction with the Bretton Woods institutions, sought to play two complementary roles, as both supporter and enforcer of structural adjustment policies.

\section{Regionalism and the new constitutionalism}

The correlation between European and global development frameworks as displayed through the Cotonou Agreement is further demonstrated in the shared strategy to achieve WTO compliance, namely the creation of EPAs. As such, it is a clear indication of the inter-linkages between global and regional frameworks, through cross-cutting ties of a political, economic and bureaucratic nature, and the complementary nature of locking-in strategies pursued at global, regional, state and sub-state levels.

Regionalisation has been a continual focus of the evolving relationship between the EU and the ACP, being presented as a strategy to maximise ACP production and markets and facilitate joint ventures. Aspects of the latest sub-regionalisation initiative embodied in the Cotonou Agreement have already been manifest in the reform efforts of several African leaders, notably Thabo

45 Hewitt 1989, p. 308. 
Mbeki of South Africa. ACP support for increased regionalisation based on neoliberal orthodoxy is evident in the form of the existing regional organisations such as the Southern African Development Community (SADC), the Common Market of Eastern and Southern Africa (COMESA) and the Economic Community of West African States (ECOWAS). The objectives of these organisations include the free movement of labour, goods, services, capital and technology, macro-economic co-ordination and convergence, liberalisation of external payments and convertibility, regional currency zones, promotion of cross border investments, regional financial/capital stock exchanges, export credit guarantee schemes and infrastructural development. ${ }^{46}$ As such, the organisation of these regional groupings is characteristic of a new type of open, outward-orientated regionalism designed to promote competitiveness and integration within the global economy. ${ }^{47}$

This 'new regionalism' represents a substantial 'locking-in' of the dominant neoliberal paradigm and surrenders important future policy options for individual governments; options that may well be required in changing national, regional or global circumstances. ${ }^{48}$ As with other aspects of the locking-in project, the new regionalism has been promoted from within Africa as well as imposed from outside. It is one of the central principles of the African-authored New Partnership for African Development (NEPAD) sponsored by South Africa, Algeria, Nigeria and Senegal, and promoted extensively by the New Labour government in the UK.49 The 'new regionalism' provides a mechanism to lock-in the neoliberal development model into both the state and civil society, providing the necessary political anchorage to institutionalise the dominance of capital over the long term.

SADC exemplifies this new regionalism and specifically seeks to adjust developmental needs to the challenges of the liberalised global economy through a regional framework for development, diversification, productivity and export capacity. Central to this strategy is to increase the ability of the region to attract capital by displaying opportunities for trade and investment. ${ }^{50}$ However, in practice, regional integration under the leadership of South Africa, has meant the penetration of the region by South-African and international capital, under the leadership of the South-African government

\footnotetext{
46 ACP Group 1998, p. 22.

47 Stubbs 2000, p. 231.

48 Keet 1999, p. 9.

49 See Government of the Republic of South Africa 2001.

50 Taylor 1999 , p. 3.
} 
and rhetorical guise of an 'African Renaissance' ${ }^{51}$ As regional integration has worked heavily towards the advantage of the South-African economy, persistent concerns over South-African dominance and uneven gains in its' favour have become enhanced. ${ }^{52}$

The strategy to attract capital dovetails with Cotonou's EPA agenda. This is demonstrated by the initiation of negotiations between the EU and SADC in July 2004,53 although engagement with this project has both promoted and detracted from the coherence of Southern-African regionalism. The six SADC member states that were also members of the Common Market for East and Southern Africa (COMESA) have chosen to pursue an EPA as part of an Eastern and Southern Africa (ESA) grouping. ${ }^{54}$ The remaining SADC states have chosen to form a separate stand-alone EPA with the EU, with South Africa adopting observer status to the negotiations. However, taking into account the existing bilateral Trade, Development and Co-operation Agreement (TDCA) between South Africa and the EU, applied de facto to Botswana, Namibia, Lesotho and Swaziland (BNLS) via the Southern African Customs Union (SACU), a free trade area is already in place. The complication arises with the inclusion of Mozambique, Angola and Tanzania in the EPA as these states are LDCs and as such are granted non-reciprocal preferential access to the EU market via the EBA initiative. ${ }^{55}$

The complexity of membership between the burgeoning African regional organisations displays their cross-cutting character. This is intensified by the multiplicity of relations created with outside actors. For example, the open nature of Southern-African regionalism has been further demonstrated by proposals to create a free-trade agreement between the US and SACU under the African Growth and Opportunity Act (AGOA). ${ }^{56}$ Mbeki has been proactive in building links throughout the world, establishing strong relations with Washington via the US-South Africa Bilateral Commission, being a regular participant at gatherings of the G8, transnational meetings such as the World Economic Forum and the Partnership Africa Conferences, and,

51 Taylor 1999 , p. 4.

52 Keet 1999, p. 1; Chazan et al. 1999, p. 315.

53 European Commission 2004.

${ }^{54}$ Negotiations have been initiated across Africa for the creation of EPAs. Talks between the EU and the Economic Community of Western African States (ECOWAS) plus Mauritania began in October 2003 as did talks between the EU and the Central African Economic and Monetary Community (CEMAC) plus Sao Tomé and Principe.

55 Davis and Goodison 2004.

56 Action for Southern Africa 2002. 
more recently, the World Summit on Sustainable Development held in South Africa. This reflects a desire to attract international capital to the region with Pretoria presenting itself as a bridge between the developed world and the South.

Through SADC, the deepening penetration of the region by the alliance of domestic and transnational capital has gone hand in hand with the promotion of transparency, good governance, security and democracy. ${ }^{57}$ This is further reflected in South-African calls for the redefinition of the Organisation of African Unity, now the African Union, and SADC as disciplinary organisations to safeguard regional 'security'. For example, through the creation in 1996 of the SADC Organ for Politics, Defence and Security: 'The aim seemingly promoted by Pretoria is to establish mechanisms to interfere in the internal affairs of member states in the event of a breakdown in governance'. ${ }^{58}$ This focus on security, peacebuilding and conflict prevention was integrated in the Cotonou Agreement, further expanding the remit of EU-ACP relations and ensuring a system of peer surveillance and discipline.

The heavy promotion of regional projects via Cotonou is an important part of the multi-levelled locking-in project. The creation of cross-cutting and intertwined institutions facilitates the extension of capital, exemplified by burgeoning EU and US relations with SADC. While the formation of such institutions will be problematic, the potential gains for capital are highly significant.

\section{Brokering class alliances: completing the world market for capital, services and labour}

Central to the multi-levelled analysis of re-designing and locking-in has been the fostering of supportive class alliances across the core and periphery. Such class alliances have been vital for the construction of globally integrated flexible production chains, and in mitigating reactions to the establishment of a global neoliberal accumulation model. Within the Lomé/Cotonou relationship, European policy has emphasised the importance of ACP privatesector development, aimed at engendering an entrepreneurial class and a culture of enterprise. The EU looked to develop strategies to encourage capital alliances and create supportive networks of foreign and local capital, officials 
and politicians. To do so, Lomé provisions sought to encourage the creation of small and medium enterprises (SMEs) and micro-projects that could enter into joint ventures with European capital. ${ }^{59}$ Through such schemes as subcontracting agricultural processing and partnerships between European and local enterprises, SMEs can become vehicles for the strengthening of integrated transnational production. ${ }^{60}$

The focus has been on the widespread adoption of an economic development model designed to strengthen market forces, increase competition and refocus the role of the state as an enabler and contractor rather than a direct economic agent. The private sector is perceived as an engine of economic growth in the ACP countries and its development has been closely associated with the achievement of the major objectives of development co-operation, such as sustainable economic and social development, integration into the world economy and poverty alleviation. As such, the Lomé/Cotonou relationship has helped to promote the necessary elements of global neoliberal accumulation.

In support of a nascent enterprise culture, the Lomé Convention included a focus on enterprise development, aimed at restructuring the productive base of the ACP. The particular emphasis on the local processing, marketing, distribution and transport of raw materials represented a combination of ACP concern for local processing and the promotion of opportunities for European investment. In 1998, the Commission introduced a new strategy for privatesector development in the ACP, in order to provide a more co-ordinated and comprehensive approach to the specific constraints of the ACP countries and regions.

Alliances between foreign and domestic capital and the state have been fostered by encouraging organisations, such as the African Employer

59 The new chapter regarding micro-projects under Lomé II was aimed at small rural projects and was funded by a tripartite structure in which EDF funding was matched by the ACP states and the recipient group. Therefore, such projects were dependent on close local capital/state interaction, and limited to relatively integrated social groups.

${ }^{60}$ This approach correlated with that of the leading international organisations. Jean-Jacques Oeschlin, chairman of the International Organisation of Employers and vice-chairman of the ILO board, described the role of the SMEs as threefold: first, as an element of control in the national economy, operating as employers and operators in regions that large organised firms sometimes cannot reach due to cost; second, a channel for adaptable technology; and, third, a transmission shaft between highly organised MNCs and the informal sector, working in tandem with large enterprise through sub-contracting. This followed the example of Japan, where large MNCs partnered a constellation of small sub-contracting firms. Oeschlin identified Africa as a region where MNCs did not, but could with encouragement, sub-contract and form partnerships with local enterprise. European Commission 1984, p. 32. 
Organisation, to facilitate co-operation, aided by institutions created to meet this aim. ${ }^{61}$ Primary amongst these has been the Centre for Industrial Development (CDI), established with the explicit aims of promoting joint ventures, sub-contracting, the export of expertise and technology and cooperation between ACP and European states and business interests. ${ }^{62}$ The aim of creating 'durable partnerships', especially joint ventures, was that:

... the ACP firm gains access to the European partner's industrial and managerial expertise, his technical and financial know-how and even access to his partner's markets. The advantage for the EU company is his partner's knowledge of local markets, access to local raw materials and a stake in an existing business and workforce. ${ }^{63}$

The CDI-assisted ACP companies to choose appropriate European partners and to locate sources of finance (development financial institutions, export credit facilities, share capital). This was based upon the assumption that prospects for other sources of private lending would be enhanced by such partnerships.

The CDI was expanded under Cotonou to become the Centre for the Development of Enterprise (CDE), reflecting the increased importance of the service sector. Trade promotion and the development of services, particularly tourism, information technology and communications, have been increasingly highlighted as areas of growth potential and interest to European capital, with the Convention including provisions to liberalise these sectors. Investment guarantees and re-insurance schemes for FDI were designed to reduce risk and induce private capital flows by boosting investor confidence, with specific investment protection and promotion agreements concluded between EU and ACP member states. The objectives of the newly expanded CDE are to bring together ACP and EU capital, promote partnerships between ACP and EU contractors, inform EU capital of investment and business opportunities and support regional integration. Sectors eligible for such support are industry and agricultural processing, construction, tourism, telecommunications, transport, the private management of infrastructure and support services.

The emphasis on building alliances between Europe and the ACP has been reflected in the ongoing focus on decentralised co-operation and building

61 European Commission 1984, p. 33.

62 European Commission 1997, p. 19.

63 Ibid. 
links between social and economic partners. There is also a continuation of the desire to prevent and mitigate the social conflict that might arise from re-designing and locking-in. The expectation is that such a strategy would produce the supportive political coalitions and stability necessary for the continued expansion and reproduction of capital. ${ }^{64}$ Additionally, supportive measures included the targeting of adjustment funds to social services, especially health and education. ${ }^{65}$ This strategy has been augmented under the Cotonou Agreement to include provisions related to peace building and conflict prevention which aim to secure conditions for investment and accumulation. Again, this fits with the broader global development agenda and in respect to the liberalisation of public services (under the General Agreement on Trade in Services in the WTO) is noticeably similar to UK government attempts to make its domestic markets a home for a newly emerging band of service companies. In this context, provisions globally and within the Cotonou relationship to link liberalisation and institutional redesigning of the state around the enabling model may appear to be an attempt to make the world safe for European capital. As Cammack has argued, with reference to the title of an influential UK Department for International Development White Paper, other measures to secure investment conditions at the same time as the adoption of pro-poor policies and poverty reduction look rather like an attempt to make 'the poor work for globalisation' ${ }^{66}$

Poverty reduction, or, in the case of the UK, 'elimination', is a crucial element of class politics not only within the EU-ACP relationship but between the developed and developing world more generally. It has become the dominant theme of World Bank development programmes, as contained within the World Bank's Comprehensive Development Framework, the Poverty Reduction and Growth Strategy approach and NEPAD, and is focused particularly on completing the world market for labour. ${ }^{67}$ The vehicle for poverty reduction is portrayed as increased integration in the global economy through trade and capital liberalisation and attracting inward investment through an enabling state capable of providing an attractive, compliant and skilled workforce. ${ }^{68}$ The result, globally, is to guarantee an excess supply of labour in the interests

${ }^{64}$ Cheru and Gill 1997, p. 151.

65 Hewitt 1989, p. 308.

66 Cammack 2001.

67 See Cammack 2002.

68 See, DFID 2001, Government of the Republic of South Africa 2001, World Bank 2001. 
of maintaining an adequate and sufficiently pliant global workforce for integrated transnational production with an internally competitive, and thus fragmentary, dynamic designed to boost and secure absolute surplus-value. Measures to improve the quality of labour inputs aim to complement this by raising the rate of relative surplus-value.

\section{Conclusion}

The evolution of the Lomé and Cotonou Agreements has complemented the global shift to neoliberal accumulation. Through these agreements, the EU has played a lead role in re-designing the development strategies of African states and has been central to the 'locking-in' project that enshrines those re-designed strategies into technical-legal, political-institutional, sociopsychological frameworks at a host of levels, including domestic political economies and inter-regional agreements. The way in which these levels overlap and fit together is central to a nascent global constitution for neoliberal accumulation, where policy alternatives are restricted to those beneficial to accumulation. Over time, the aims of this global constitutionalism, including the Lomé and Cotonou agreements, have centralised not only the expansion of the world market in primary commodities and finished goods, but now also the completion of a world market for services, capital and labour as well. This represents the expansion of commodification to new and unprecedented levels.

Neoliberal global constitutionalism is not an unproblematic project and has resulted in widespread unease, as witnessed by global mass protests, located at meetings of world leaders and the key global institutions (including the EU). However, this article has demonstrated that the construction of capitalist hegemony is highly self-reflexive. At key junctures, interventions have sought to defend and shore up the dominance of capital. The early phase of neoliberal ascendancy was marked by strategies to deconstruct the class basis of opposition through structural adjustment and austerity. More recently, the increased focus on poverty reduction and pro-poor policies has demonstrated a fear of 'dropping-out' of the capitalist economy and more inclusive and participatory forms of development strategies witness a desire to build supportive alliances behind this project. Ironically, however, the inherent rigidity represented in the institutionalised structures of 'locking-in' may well undermine the ability of neoliberal hegemony to respond in the future to the pressures of instability and change. 


\section{References}

Action for Southern Africa (Actsa) 2002, Trade and Development Update, 2, 5 (November).

African, Caribbean and Pacific Group of States (ACP Group) 1998, ACP Group Negotiating Mandate ACP/28/028/98 September, Brussels: ACP Secretariat.

Arrow, Kenneth 1962, 'The Economic Implications of Learning by Doing', Review of Economic Studies, 29, 3: 155-73.

Brown, William 2002, The European Union and Africa: The Restructuring of North-South Relations, London: I.B. Tauris.

Cammack, Paul 1999, 'Interpreting ASEM: Interregionalism and the New Materialism', Journal of the Asia-Pacific Economy, 4, 1: 13-32.

Cammack, Paul 2001, 'Making the World's Poor Work for Globalization', New Political Economy, 6, 3: 397-408.

Cammack, Paul 2002, 'The Mother of All Governments: the World Bank's Matrix for Global Governance', in Global Governance: Critical Perspectives, edited by Rorden Wilkinson and Steve Hughes, London: Routledge.

Cammack, Paul 2003, 'The Governance of Global Capitalism: A New Materialist Perspective', Historical Materialism, 11, 2: 37-59.

Chazan, Naomi, Peter Lewis, Robert Mortimer, Donald Rothchild, Stephen Stedman 1999, Politics and Society in Contemporary Africa, Basingstoke: Macmillan.

Cheru, Fantu and Stephen Gill 1997, 'Structural Adjustment and the G-7: Limits and Contradictions', in Globalization, Democratization and Multilateralism, edited by Stephen Gill, Hampshire: Macmillan.

Collier, Paul 1998, Living Down the Past: How Europe Can Help Africa Grow, London: Institute of Economic Affairs, Trade and Development Unit.

Dans, Theodor 1977, 'Agricultural Co-operation and the Lomé Convention', in The Lomé Convention and a New International Economic Order, edited by Frans A.M. Alting von Geusau, Leiden: A.W. Sijthoff.

Davies, Rob and Paul Goodison 2004, Making Economic Partnership Agreements Work for Development in Southern Africa, available at: <http://www.tralac.org/scripts / content.php?id=2477>.

Department for International Development (DFID, UK Government) 2000, Eliminating World Poverty: Making Globalization Work for the Poor: White Paper on International Development, available at: <http://www.dfid.gov.uk/>.

European Commission (EC) 1978, The ACP-EEC Courier, 48, Brussels: EC.

European Commission (EC) 1979a, The ACP-EEC Courier, 54, Brussels: EC.

European Commission (EC) 1979b, 'Special Issue', The ACP-EEC Courier, 58, Brussels: EC.

European Commission (EC) 1984, The ACP-EEC Courier, 84, Brussels: EC.

European Commission (EC) 1985, 'Special Issue', The ACP-EEC Courier, 89, Brussels: EC.

European Commission (EC) 1986, Ten Years of Lomé: A Record of ACP-EC Partnership 1976-1985, Brussels: EC.

European Commission (EC) 1989, The ACP-EC Courier, 114, Brussels: EC.

European Commission (EC) 1990, The ACP-EC Courier, 120, Brussels: EC. 
European Commission (EC) Directorate General for Economic and Financial Affairs 1992, Lessons from the Stabilization Programmes of Central and Eastern European Countries, 1989-91, Economic Papers 92, Brussels: EC.

European Commission (EC) Directorate General for Development 1995, Industrial and Economic Co-operation between the European Union and the Developing Countries, Luxembourg: Office for Official Publications of the European Communities.

European Commission (EC) 1996, Lomé IV Revised: Changes and Challenges, Luxembourg: Office for Official Publications of the European Communities.

European Commission (EC) 1996, The Courier Special Issue: EU-ACP Co-operation in 1994, Brussels: Steffen Smidt.

European Commission (EC) Directorate General for Development 1997, European Community Support for the Private Sector in the ACP Countries, Luxembourg: Office for Official Publications of the European Communities.

European Commission (EC) 2000, The Courier Special Issue: The Cotonou Agreement, Brussels: Directorate General for Development.

European Commission (EC) Directorate General for Development 2004, Weekly News 19/7/2004 available at: <http:/ / europa.eu.int/comm/development/body/news / news_en.htm>.

European Council 2000, Press Release, Counseil/00/42 2304th Council Meeting on Development, Brussels 10th November.

Gibb, Richard 2000, 'Post Lomé: The European Union and the South', Third World Quarterly, 21, 3: 457-82.

Gill, Stephen and David Law 1993, 'Global Hegemony and the Structural Power of Capital', in Gramsci, Historical Materialism and International Relations, edited by Stephen Gill, Cambridge: Cambridge University Press.

Gill, Stephen 1998, 'New Constitutionalism, Democratization and Global Political Economy', Pacifica Review, 10, 1 (February): 23-38.

Gill, Stephen 1999, 'The Constitution of Global Capitalism', paper presented to the British International Studies Association, Manchester, December 1999.

Government of the Republic of South Africa 2001, A New African Initiative: Merger of the Millennium Partnership for The African Recovery Programme and the Omega Plan, available at: <http://www.polity.org.za/govdocs/misc/mapomega.html>.

Green, Reginald H. 1976, 'The Lomé Convention: Updated Dependence or Departure toward Collective Self-Reliance', The African Review, 6, 1: 43-54.

Gruhn, Isabel 1976, 'The Lomé Convention: Inching Towards Interdependence', International Organization, 30, 2: 241-62.

Hewitt, Adrian and Christopher Stevens 1981, 'The Second Lomé Convention', in EC and the Third World: A Survey, edited by Christopher Stevens, Kent: Hodder and Stoughton.

Hewitt, Adrian 1989, 'Development Assistance Policy and the ACP', in The European Community and the Challenge of the Future, edited by Juliet Lodge, London: Pinter Publishers.

International Monetary Fund 1983, 'Recent Multilateral Debt Restructurings with Official and Bank Creditors', IMF Occasional Paper, 25, Washington DC.: IMF.

International Monetary Fund 1988, Privatization and Public Enterprise, Washington DC.: IMF. 
International Monetary Fund 1995, Annual Report, Washington DC.: IMF.

Kaldor, Nicholas and James Mirlees 1962, 'A New Model of Economic Growth', Review of Economic Studies, 29, 3: 174-92.

Keet, Dot 1999, The Implications of the EU's Proposed 'Regional Economic Partnership Agreements' with Respect to Regional Integration and Development in Southern Africa, available at: <http://aidc.org.za/archives/dkeet_regional_economic_partnership. html>.

Lindblom, Charles 1977, Politics and Markets: The Worlds Political and Economic Systems, New York: Basic Books.

Long, Frank 1980, 'Transnational Corporations, Technology Transfer and Lomé', in The Political Economy of EC Relations with African, Caribbean and Pacific States, edited by Frank Long, Oxford: Pergamon.

Marx, Karl and Friederich Engels, 1985, The Communist Manifesto, London: Penguin Classics.

Moss, Joanne and John Ravenhill 1987, 'The Evolution of Trade under the Lomé Conventions: The First Ten Years', in EC and the Third World: A Survey 6, edited by Christopher Stevens, London: Hodder and Stoughton.

Poulantzas, Nicos 2000, State, Power, Socialism, London: Verso.

Ravenhill, John 1985, Collective Clientelism: The Lomé Conventions and North-South Relations, New York: Columbia University Press.

Rubin, A. 1978, Lomé II: The Renegotiation of the Lomé Convention, London: Catholic Institute for International Relations.

Selowsky, Robert June 1987, 'Adjustment in the 1980s: An Overview of Issues', World Bank and IMF, Finance and Development, Autumn.

Stevens, Christopher (ed.) 1983, The EC and the Third World: A Survey 3, London: Hodder and Stoughton.

Stubbs, Richard 2000, 'Regionalization and Globalization', in Political Economy and the Changing Global Order, edited by Richard Stubbs and Geoffrey Underhill, Oxford: Oxford University Press.

Taylor, Ian 1999, 'South Africa's Promotion of "Democracy" and "Stability" in Southern Africa: Good Governance or Good for Business?', paper presented to the Centre for the Study of Globalization and Regionalization third annual conference, 'After the Global Crises: What Next for Regionalism', University of Warwick, 16-18 September 1999.

World Bank 1985, World Development Report, Washington: World Bank.

World Bank 1991, World Development Report, Oxford: Oxford University Press.

World Bank 2001, Poverty Reduction and Growth Strategy Papers, available at: <http://www.worldbank.org/poverty/strategies/>. 